\title{
Is Authoritative Parenting the Best Parenting Style?
}

\author{
Anita Febiyanti ${ }^{1, *}$, Yeni Rachmawati ${ }^{2}$ \\ ${ }^{1,2}$ Department of Early Childhood Education, School of Postgraduate, Universitas Pendidikan Indonesia \\ *Corresponding author. Email: anitafebiyanti@upi.edu
}

\begin{abstract}
Over the past 60 years, parenting style has been consistently explored, particularly with regard to its role in children's development in western society. Various studies show that authoritative parenting is the best and the most effective parenting style to be applied universally to support optimal children's development. This paper aims at exploring how the implementation of parenting style is highly affected by the cultural context of the society. Different cultural values reflected in individualist and collectivist cultures shape different understandings of parenting and thus different parenting styles. The two cultures perceive authoritative parenting style differently. To collect information, the author reviewed the literature on parenting practices in Asian, European, and American countries. The results of this paper highlight the need of having a better understanding on how the parenting style which is considered the best in one culture can be distinctly perceived by other cultures.
\end{abstract}

Keywords: Children, parenting, early childhood education.

\section{INTRODUCTION}

Parenting plays a significant role in all of children's development [1]. Parenting style is an approach used by parents to introduce culture and environment to their children. Parents generally tend to have the biggest influence on children's development because the parentchild interaction is frequent and repetitive. Parenting is an activity that involves physical and environmental factors through daily interaction processes to develop all aspects of children's development and shape their character [2], [3], [4]. Parenting is influenced by many factors, one of which is culture [5].

Parenting cannot be separated from the postcolonial condition. Most of the parenting practices today are based on western theory and practice, such as Baumrind's parenting theory and parenting programs, such as TripleP (Positive Parenting Program) [6], Nurturing Parenting Programs [7], PEP (Parents Encouragement Program) [8] and many more. Baumrind's theory predominantly informs research on parenting in various countries, including Asian countries. The theory explains four parenting styles, one of them is authoritative parenting that is mostly applied in Europe and America. The impact of globalization and the stereotype that everything comes from western is the best [9] make authoritative parenting considered the best parenting style and can be applied universally to optimally support children's development and academic performances. However, research in China [10] suggests that authoritative parenting is not related to a student's academic performances. Based on the literature review, the author is motivated to find out more about the authoritative parenting style in different cultures.

This paper is organized as follows. Section 1 is an introduction. Section 2 describes the most common differences in parenting styles. Section 3 is the paradigm used by researchers which produce criticism of parenting theories in section 4. Section 5 discusses parenting in different cultural contexts. Finally, section 6 concludes the paper.

\section{AUTHORITARIAN VS AUTHORITATIVE PARENTING STYLE}

As explained in the introduction, the concept or theory that is commonly referenced in research on parenting is that of Diana Blumberg Baumrind. Baumrind was an expert developmental psychologist from the United States who researches parenting styles. She categorizes parent's behaviour toward children into two dimensions, namely parental demandingness and parental responsiveness [11]. Parental demand refers to the extent to which parents expect and demand children's maturity and responsibility meanwhile, parental responsiveness refers to a parent's general tendency in providing warmth, support, acceptance, and positive response towards the children's needs [12].

The combination of parental demandingness and parental responsiveness results in four parenting styles, 
which are authoritative style, authoritarian style, permissive style, and neglectful style [11]. The combination of high control and low responsiveness makes an authoritarian parenting style, whereas the combination of high control and high responsiveness creates an authoritative parenting style. The combination of low control and high responsiveness yields a permissive parenting style, and the combination of low control and low responsiveness creates a neglectful parenting style.

Authoritarian and authoritative styles are the two most common parenting styles. Since those two styles show a high level of control, authoritarian and authoritative parenting styles only differ in the level of support. Other researchers have noted that the control exerted by parents' styles become the characteristics of the two parenting styles [11], [13]. The control of authoritarian parents is very direct and demanding, while the control of authoritative parents is characterized by cooperative and being assertive. Authoritarian parents try to guide children by dominating most of their interactions and enforce obedience based on the provided directions, meanwhile authoritative parents try to support children to be the one who can reveal the opinions and maintain their personal perspectives [2].

\section{POSTCOLONIAL PERSPECTIVE}

This research is based on postcolonial theory. Although postcolonial theory varies [14], the main objective remains the same, that is to explore, understand, and analyse sharply the diversity of continuities of colonialism in the contemporary world [15]. According to Said, colonialism prevails through the persistence of colonial hierarchies of knowledge that promote some cultural diversity [16]. From a postcolonial perspective, the definition of colonialism includes domination of a country over other countries, global over local, domination of one knowledge and discourse over others [17]. Colonial legacy persists even when the country is no longer colonized; moreover, it controls people's minds [18], [19].

Matters in Global South countries such as African and Asian countries are often frequently assumed to be attributable to the development standards and norms developed in Global North such as America and Europe, creating an idea that everything coming from the Global North is preferential and shall be the norm. Therefore, non-western parenting is often perceived as inadequate parenting, requires correction, and has low values, causing the parenting to be regarded as "the other". The othering raises the subaltern, which in this matter, refers to people implementing non-western parenting. According to Gramscian theory [20], the subaltern is a group of people of a certain race, social status, gender, and culture that is seen as an underclass/a low-rank people.
The continuous effects of colonialism are also seen in the existing parenting programs. The research conducted by Leung, Sanders, Mak, \& Lau in Hongkong [21], Matsumoto in Japan [22], Sumargi in Indonesia [23], and Guo in China [24] showed how parenting in those countries was influenced and based on the western theories. Western theories of parenting have been criticised as the practices are often different from the theories; furthermore, they lack cultural sensitivity.

\section{CRITICISM OF PARENTING THEORIES}

There is quite a large amount of research on parenting. Baumrind's theory highly dominates research on parenting in many countries, including Asian countries. A study in the United States using the European-American middle-class children as a sample entirely promotes the notion that the authoritative parenting style was always related to children's ultimate success [25], [26]. Berger states that the authoritative parenting style is the recommended parenting style since children who are raised democratically will achieve success, are reliable, and are responsible [27]. The many claims made by the researchers on the universality of authoritative parenting and the repetitive propagandas strengthen the opinion that the best parenting style is authoritative so that it becomes a regime of truth and a worldwide standard of parenting style [28].

On the other hand, the research of Deater \& Dodge in Africa questioned the idea of the authoritative parenting style which was always related to the optimal compliance among children and teenagers [29]. Accordingly, there are controversies of whether authoritative parenting has the same impacts on non-European children and teenagers. This questioning is strengthened by the research of Watabe and Hibbard in Japan [30], Chen and Wong in China [31] which indicates that the authoritarian parenting style gave a positive result on children's academic accomplishments.

The relationship between the authoritative parenting style and student's academic achievements is only valid among European-Americans [32]. Chao argues that nonAmerican-Europeans interpret the meaning of the authoritarian parenting style differently [33]. For them, authoritarian parents are defined as parents who care, control, and pay attention to children; however, for American-Europeans, those behaviours are very controlling and dictatorial for children.

The definition of parenting is also a bias as the norms and standards applied tend to follow the western countries, whereas parenting style is highly influenced by the culture and ethnicity in which the people live. The best method of parenting and knowledge about what children shall learn are derived from cultural knowledge which are introduced and preserved from one generation 
to the next generation [34]. The parenting standard has been universalized because the parenting scale used in the Global North is adapted in the Global South [35]. It can be confirmed that the indicators of the measuring instrument are not suitable for a certain cultural context so that parents are forced to answer based on the determined standards.

\section{PARENTING IN DIFFERENT CULTURAL CONTEXT}

The most noticeable differences in parenting practices are the rarity of authoritative parenting in nonwestern cultures. Authoritarian parenting is perceived as a traditional/primitive parenting style [36]. Non-western parents expect their children will obey and be respectful of what is instructed without getting resistance, so that those parents carry inherent authority than it does in the west. Does this mean authoritarian is typical of traditional/primitive parenting style? That is not the case.

Traditional cultures are generally inclined towards the authoritative parenting style because they tend to be high in demandingness and responsiveness; however, their demandingness is very different from the authoritative parents in western countries. The differences in demandingness are caused by the differences between the two cultures. According to Wishnuwardhani and Mangundjaya, Global North countries have individualist cultures regardless of the society and they only focus on themselves; meanwhile, Global South countries have cultural values where the people are attached to a strong bond and every individual is obligated to maintain group loyalty and focus on the communities in which they live [37].

Cultural values and aspirations are transmitted from one generation to another through the practices of parenting. Bornstein contends that cultures influence parenting as the cultural belief and the attitude of parenting practice are preserved and transmitted [5]. Accordingly, different cultural experiences in the practice of parenting shape an individual that is different from one another. Parenting attitude is influenced by direct and non-direct effects of the individualist and collectivist cultures.

Individualist and collectivist cultures refer to how individuals perceive themselves in a relationship with the other member of the society [38]. Collectivism highly stresses the interdependent relationship with one another; in contrast, individualism stresses self-independency [39]. The two cultural orientations are related to a different way of thinking and behaving, such as emotions, moralities, goals, and social relationships. A society that develops characteristics of individualism supports emotional independence, assertiveness, autonomy, and the need for privacy where the individual loosens its bound with the others [40]. On the contrary, collectivism prioritizes socialization, obedience, security, and family integrity [41]. The different thoughts and behaviours between the two cultures cause differences in the fundamental basics of parenting attitude and its results in children of various cultural communities.

In collectivist countries, individuals shall learn to refrain from expressing self-desire and helping one another. Parents teach values, such as being helpful, obedient, and interdependent in a group as a family and a country. Parents imply strict control, rules, and warning [42]. Meanwhile, in individualist countries, parents tend to adopt a more democratic parenting style since in individualist cultures, autonomy, independence, and selfinterest are the focus in socialization [43]. Contextually, they stress negotiation and responsiveness toward children. Collectivist cultures have different motivations from individualist cultures in embedding values of respecting the group. Kagitcibasi argues that in collectivist cultures, children perceive strong control of parents as a normal thing and it does not always reflect parent's cruelty because it shown care and concern; on the other hand, in individualist cultures, parent's strong control is considered as dictatorial and reflects the cruelty of the parents [38]. It has been shown that cultural factors, such as race, ethnicity, and social-economic status influence parenting styles. This statement is strengthened by research conducted by Rebecca showing that a study in Singapore among ethnic Chinese, Indian, and Malay groups showed that authoritarian parents make Malay teenagers able to adjust their behaviour better in their school [44]. Authoritarian parenting style was more related to positive development outcomes if the social environment of family and society provides good responses in accordance with the parenting style.

\section{CONCLUSION}

It can be concluded that parent's behaviour and involvement play a significant role in parenting. The western parenting practices and theories still have a strong impact and are predominant, so anything that is not in line with them will be perceived as wrong and different. There are different viewpoints regarding authoritative and authoritarian parenting in the context of different cultures because parenting behaviour and its impacts differ from one culture to another. Every culture develops its patterns in raising children. Matters that are considered good in one culture can be considered as maladaptive by another culture.

In collectivism, parents' closeness to children and parental responsiveness are shown by rules, guidelines, and monitoring. Conversely in individualism, parents' closeness to children and parental responsiveness are shown in a democratic way with warm hugs and praise. So, parents who control their children represent a negative parenting style in the individualist group 
because it is not appropriate with their culture norms. Therefore, the meaning of the best parenting style tends to be influenced by the norms and values in the respective culture.

\section{ACKNOWLEDGMENTS}

This paper is supported by various parties. Our thanks go to the Institute for Research and Community Service Universitas Pendidikan Indonesia, The Ministry of Research and Technology of Indonesia and Ethno parenting research team

\section{REFERENCES}

[1] Belsky J, De Haan M. Annual Research Review: Parenting and children's brain development: The end of the beginning. Journal of Child Psychology and Psychiatry [Internet]. 2011;52(4):409-28. Available from: https://acamh.onlinelibrary.wiley.com/doi/ab s/10.1111/j.1469-7610.2010.02281.x.

[2] Baumrind D. Parental disciplinary patterns and social competence in children. Youth \& Society [Internet]. 1978;9:239-267. Available from: https://journals.sagepub.com/doi/abs/10.1177/0044 $118 \times 7800900302$

[3] Brooks J. The process of parenting. New York: McGraw-Hill Education; 2010.

[4] Morrison FJ. Parenting and academic development. Merrill-Palmer Quarterly [Internet]. 2009;55:36172. Available from: https://www.jstor.org/stable/23 096262? seq $=1$

[5] Bornstein MH. Cultural approaches to parenting. Parenting [Internet]. 2012;12(3):212-221. Available from: https://www.tandfonline.com/doi/abs/10.10 8 0/15295192.2012.683359.

[6] Sanders MR. Development, evaluation, and multinational dissemination of the Triple P-Positive Parenting Program [Internet]. Annual Review of Clinical Psychology. 2012;8:345-79. Available from: 10.1146/annurev-clinpsy-032511-143104.

[7] Bavolek SJ. Nurturing parenting programs for the prevention of child maltreatment. In: James J, Ponzetti, JR, editors. Evidence-based Parenting Education. New York: Routledge; 2016. pp.206-24.

[8] Jessup LE, Baldwin EL. Parenting with courage and uncommon sense. United States: Create Space Independent Publishing Platform; 2015.

[9] Chakkarath P. Stereotypes in social psychology: The "West-East" differentiation as a reflection of western traditions of thought. Psychological Studies (Mysore). 2010;55(1):18-25.

[10]Cheah CSL, Leung CYY, Tahseen M, Schultz D. Authoritative parenting among immigrant chinese mothers of preschoolers. Journal of Family
Psychology [Internet]. 2009;23(3):311-20. Available from: https://psycnet.apa.org/record/ 2009 -08598-005.

[11]Baumrind D. The influence of parenting style on adolescent competence and substance use. The Journal of Early Adolescence [Internet]. 1991;11(1):56-95. Available from: https://journals .sagepub.com/doi/abs/10.1177/0272431691111004.

[12]Baumrind D. Rearing competent children. In: Damon W, editor. The Jossey-Bass social and behavioural science series, child development today and tomorrow. San Fransisco: Jossey-Bass; 1989. pp. 349-78.

[13]Berns RM. Child, family, school, community: Socialization and support. Belmont: Nelson Education; 2012.

[14] Young RJC. Postcolonialism: An historical introduction. West Sussex: John Wiley \& Sons; 2016. Available from: https://sci-hub.do/10.1002/97 81119316817.

[15]Hall S. When was the "Post-colonial?": Thinking at the limit. In: Chambers, Lidia C, editors. The PostColonial Question. New York: Routledge; 1996. pp. 242-53.

[16] Said EW. Representing the colonized: Anthropology's interlocutors. Critical Inquiry [Internet]. 1989;15(2):205-25. Available from: https://www.journals.uchicago.edu/doi/abs/10.1086 /448481? journalCode=ci.

[17] Subedi B, Daza SL. The possibilities of postcolonial praxis in education. Race Ethnicity and Education [Internet]. 2008;11(1):1-10. Available from: https://www.tandfonline.com/doi/abs/10.1080/1361 3320701845731 .

[18] Childs P, Williams RJP. An introduction to postcolonial theory. New York: Routledge; 2014 Available from: https://sci-hub.do/10.4324/978131 5847481 .

[19] Spivak GC. Translation as culture. Parallax [Internet]. 2000;6(1):13-24. Available from: https://www.tandfonline.com/doi/abs/10.1080/1353 46400249252? journalCode $=\operatorname{tpar} 20$.

[20] Green ME. Rethinking the subaltern and the question of censorship in Gramsci's prison notebooks. Postcolonial Studies [Internet]. 2011;14(4):385402. Available from: https://www.tandfonline.com /doi/abs/10.1080/13688790.2011.641913.

[21]Leung C, Sanders MR, Leung S, Mak R, Lau J. An outcome evaluation of the implementation of the Triple P-Positive Parenting Program in Hong Kong. Family Process [Internet]. 2003;42(4):531-44. Available from: https://onlinelibrary.wiley.com /doi/abs/10.1111/j.1545-5300.2003.00531.x. 
[22] Matsumoto Y, Sofronoff K, Sanders MR. The efficacy and acceptability of the Triple P-Positive Parenting Program with Japanese parents. Behaviour Change [Internet]. 2007;24(4):205-218. Available from: 10.1375/bech.24.4.205.

[23] Sumargi A, Sofronoff K, Morawska A. A randomized-controlled trial of the Triple P-Positive Parenting Program seminar series with Indonesian parents. Child Psychiatry \& Human Development [Internet]. 2015;46(5):749-61. Available from: https://link.springer.com/article/10.1007/s10578014-0517-8.

[24] Guo M, Morawska A, Sanders MR. A randomized controlled trial of group Triple $\mathrm{P}$ with Chinese parents in Mainland China. Behavior Modification [Internet]. 2016;40(6):825-851. Available from: https://journals.sagepub.com/doi/abs/10.1177/0145 445516644221.

[25]Liem JH, Cavell EC, Lustig K. The influence of authoritative parenting during adolescence on depressive symptoms in young adulthood: Examining the mediating roles of self-development and peer support. The Journal of Genetic Psychology [Internet]. 2010;171(1):73-92. Available from: https://www.tandfonline.com/doi/full/10.1080/0022 1320903300379.

[26]Feldman R. Parenting behavior as the environment where children grow. In: Mayes LC, Lewis M, editors. Cambridge handbook of environment in human development. United Kingdom: Cambridge University Press; 2012. pp.535-67.

[27] Berger E. Parents as partners in education: Families and schools working together. New Jersey: Merrill Prentice Hall; 1995.

[28] Penn H. Travelling policies and global buzzwords: How international non-governmental organizations and charities spread the word about early childhood in the global South. Childhood [Internet]. 2011;18(1):94-113. Available from: https://journals. sagepub.com/doi/abs/10.1177/0907568210369846.

[29]Deater-Deckard K, Dodge KA. Externalizing Behavior problems and discipline revisited: nonlinear effects and variation by culture, context, and gender. Psychological Inquiry [Internet]. 1997;8(3):161-75. Available from: https://www. tandfonline.com/doi/abs/10.1207/s15327965pli080 3_1.

[30] Watabe A, Hibbard DR. The influence of authoritarian and authoritative parenting on children's academic achievement motivation: A comparison between the United States and Japan. North American Journal of Psychology. 2014;16(2):360-82.

[31] Chen WW, Wong YL. What my parents make me believe in learning: The role of filial piety in Hong
Kong students' motivation and academic achievement. International Journal of Psychology [Internet]. 2014;49(4):49-256. Available from: https://onlinelibrary.wiley.com/doi/abs/10.1002/ijo p.12014.

[32] Park HS, Bauer S. Parenting practices, ethnicity, socioeconomic status and academic achievement in adolescents. School Psychology International [Internet]. 2002;23(4):386-96. Available from: https://journals.sagepub.com/doi/abs/10.1177/0143 034302234002 .

[33] Chao RK. Extending research on the consequences of parenting style for Chinese Americans and European Americans. Child Development [Internet]. 2001;72(6):1832-43. Available from: https://srcd. onlinelibrary.wiley.com/doi/abs/10.1111/14678624.00381

[34]Fontes LA. Child discipline and physical abuse in immigrant Latino families: Reducing violence and misunderstandings. Journal of Counseling \& Development [Internet]. 2002;80(1):31-40. Available from: https://onlinelibrary.wiley.com /doi/abs/10.1002/j.1556-6678.2002.tb00163.x.

[35] Stewart SM, Bond MH. A critical look at parenting research from the mainstream: Problems uncovered while adapting western research to non-Western cultures. British Journal of Developmental Psychology [Internet]. 2002;20(3):379-92. Available from: https://bpspsychub.onlinelibrary .wiley.com/doi/abs/10.1348/026151002320620389.

[36] Silk JS, Steinberg L, Morris AS. Adolescents' emotion regulation in daily life: Links to depressive symptoms and problem behaviour. Child Development. 2003:74(6);1869-80.

[37] Wishnuwardhani PD, Mangundjaya W. Hubungan nilai budaya individualisme-kolektivisme dan gaya penyelesaian konflik. Jurnal Psikologi Sosial. 2008;14(1):5-8.

[38] Kagitcibasi C. Social norms and authoritarianism: A Turkish-American comparison. Journal of Personality and Social Psychology [Internet]. 1970;16(3):444-451. Available from: https:// psycnet.apa.org/record/1971-04049-001.

[39] Triandis HC. Individualism-collectivism and personality. Journal of Personality [Internet]. 2001;69(6):907-24. Available from: https://online library.wiley.com/doi/abs/10.1111/1467-6494.6961 69.

[40]Hofstede G, McCrae RR. Personality and culture revisited: Linking Traits and dimensions of culture. Cross-cultural Research [Internet]. 2004;8(1):52-88. Available from: https://journals.sagepub.com/doi/a bs/10.1177/1069397103259443.

[41] Oishi S, Diener E, Suh E, Lucas RE. Value as a moderator in subjective well-being. Journal of 
Personality [Internet]. 1999;24(1):1319-31. Available from: https://onlinelibrary.wiley.com/doi /abs/10.1111/1467-6494.00051.

[42] Chen X, Bian Y, Xin T, Wang L, Silbereisen RK. Perceived social change and childrearing attitudes in China. European Psychologist [Internet]. 2010;15(4):260-270. Available from: https:// psycne t.apa.org/record/2010-25456-003.

[43] Keshavarz S, Baharudin R. Parenting style in a collectivist culture of Malaysia. The Journal of Genetic Psychology. 2009;10(1):66-73.

[44] Ang RP. Effects of parenting style on personal and social variables for Asian adolescents. American Journal of Orthopsychiatry [Internet]. 2006;76(4):503-11. Available from: https://online library.wiley.com/doi/abs/10.1037/00029432.76.4.503. 